\section{Technical Education Support in Pre-Primary Education by Interactive Teaching Systems}

\section{Peter Brečka-Miriam Bitterová}

\begin{abstract}
The paper deals with the possibility of interactive whiteboard (IWB) implementation to the technical education support in the frames of pre-primary education. It also presents some types of IWB, deals with problems associated with this issue and introduces teachers' competencies needed for the work with them. The final part points out the results of the research realized in this field in the USA and in Slovakia.
\end{abstract}

Keywords: interactive whiteboards, technical education, pre-primary education, types of interactive whiteboards, teachers' competencies in interactive whiteboard use.

\section{Introduction}

Digital technologies as teaching tools have already found their place in different forms and situations in the support of technical creativity in pre-primary education. However, the individual work was dominant up till now. This has been changed by the system of interactive whiteboards used in the teaching process at pre-primary level and due to this fact they have got their place among actual trends in education supported by multimedia. The following implementation of these tools to education requires qualified teachers. In this case an important role is played by the hardware and software specification of the system and also by the fact how it could be used in this field of pedagogy.

\section{Types of interactive whiteboards}

The interactive whiteboard as a didactic technique is one of the possibilities how to innovate the teaching process in pre-primary education. This technique and teaching aids - teaching materials develop not only the cognitive functions of the personality but also the processes of creative technical thinking, imagination, they increase students' interest in studying and help to form pupils' attitudes.

On the Slovak market a lot of types of interactive whiteboards of different producers can be found. New producers follow the well-tried principles and quality software to integrate all the already used tested technological elements. Suitability of certain solutions for pre-primary education can be seen mostly in the usage of systems based on electromagnetic principle, ultrasound and infrared rays. Concrete reasons are the followings: fast echo, while writing there is no need to put high pressure on the board (as in case of resisting boards), while writing on the interactive whiteboard we prefer to use special pens - styluses, used by electromagnetic technology. Pupils learn how to use this pen correctly, fix their own psychomotor skills, eliminate mistakes etc. From the point of view of the software support IWB producers have been focusing on this age group of children and trying to create simple, interesting, graphically colourful, intuitive environment for them where they learn to work fast and without bigger problems (e.g., the software ACTIVprimary, the board Promethean ACTIVboard that is represented by a transparent floating panel of tools, icons big enough that can be reached by each child. It contains audio clips that keep children's attention and make the environment attractive).

\footnotetext{
* Peter Brečka, Department of Technology and Information Technologies, Faculty of Education of the Constantine the Philosopher University in Nitra, Slovakia; pbrecka@ukf.sk

Miriam Bitterová, Department of Technology and Information Technologies, Faculty of Education of the Constantine the Philosopher University in Nitra, Slovakia; mbitterova@ukf.sk
} 


\section{Acta Technologica Dubnicae \\ volume 2, 2012, issue 1}

The world market of interactive whiteboards is much bigger and due to this fact we introduce the following overview of some actual, commercially available IWBs. The table contains just the basic types of IWBs of given producers with selected technology of reading (some producers use in some cases more principles of IWB functioning). We do not present the products with function based on a specific technology. The mentioned products have an agreement of software usage with the main technology producer.

\begin{tabular}{|c|c|c|c|}
\hline Product & Producer & Technology - reading & Writing tools \\
\hline ActivBoard & Promethean & $\begin{array}{l}\text { Electromagnetic passive } \\
\text { Melamine surface }\end{array}$ & ActivPen - 2-button pen \\
\hline CleverBoard & $\begin{array}{l}\text { Sahara Presentation } \\
\text { Systems plc }\end{array}$ & Ultrasound - infrared & Interactive electronic pen \\
\hline eBeam & Luidia & $\begin{array}{l}\text { Ultrasound - infrared } \\
\text { China - email surface }\end{array}$ & $\begin{array}{l}\text { Electronic pen with more } \\
\text { buttons }\end{array}$ \\
\hline iBoard & $\begin{array}{l}\text { iBoard Canada } \\
\text { Manufacturing Inc. }\end{array}$ & Ultrasound - infrared & $\begin{array}{l}\text { Colourful markers + Pen + } \\
\text { digital eraser }\end{array}$ \\
\hline I-Cabinet & Mimio Virtual Ink & $\begin{array}{l}\text { Ultrasound } \\
\text { Ceramic board }\end{array}$ & $\begin{array}{l}\text { Colourful markers + Pen + } \\
\text { digital eraser }\end{array}$ \\
\hline Inspire & Interactive Technologies & Resistive & Pen, finger \\
\hline Intelliboard & Numonics & Electromagnetic & Pen \\
\hline Interwrite & GTCO CalComp & $\begin{array}{l}\text { Electromagnetic passive } \\
\text { (contactless) }\end{array}$ & $\begin{array}{l}\text { Electromagnetic rechargeable } \\
\text { pen (with } 2 \text { buttons) }\end{array}$ \\
\hline Mimio & Virtual Ink & Ultrasound - infrared & Electronic pen \\
\hline Panaboard & Panasonic & Ultrasound - infrared & Electronic pen \\
\hline PolyVision Eno & PolyVision Co. & $\begin{array}{l}\text { Bluetooth technology } \\
\text { Magnetic ceramic - steel } \\
\text { surface }\end{array}$ & Electronic pen with bluetooth \\
\hline Qomo & Qomo & $\begin{array}{l}\text { Infrared } \\
\text { China surface }\end{array}$ & 3 colourful pens, eraser, finger \\
\hline SmartBoard & SMART Technologies & Analog - resistive & $\begin{array}{l}\text { Finger }+4 \text { colourful markers, } \\
\text { erasing sponge }\end{array}$ \\
\hline Starboard & Hitachi & Ultrasound - infrared & $\begin{array}{l}\text { 3-button electronic projecting } \\
\text { pen, finger }\end{array}$ \\
\hline TeamBoard & Egan TeamBoard Inc. & $\begin{array}{l}\text { Resistive - contact reading } \\
\text { Infrared }\end{array}$ & Finger, electronic pen \\
\hline
\end{tabular}

Table 1 Overview of some selected iwb producers

To create a wider competition in sale of different IWB brands and types for schools, there has appeared a paradox connected with teaching materials for particular whiteboard types. It often happens that a school or schools in the city own more types of IWBs and this results into a problem of exchanging electronic materials that can be shared by teachers. It is generally known that "the power of information is in the ability of their exchange" (Stansbury, 2010). According to this statement the British Educational Communications and Technology Agency (BECTA) has decided to associate leaders on the UK market. It has recently announced that all the main IWB dealers have made an agreement that their educational content will be disposable in a common format. Due to the fact that these educational sources became more available, the idea of more effective technology usage has been supported. Out of the file specification (.iwb) an application for document browsing has been created (Boardviewer) and a library code can be used by the software producers for integration support to their own applications. The above integration has been agreed by the following companies in the United Kingdom: eInstruction, Hitachi, Luidia, Mimio, PolyVision, Promethean, RM, Sahara Presentation Systems, SMART Technologies and TeamBoard. Although IWB dealers in the UK have bound to deliver the iwb standard software, it will not happen immediately because specialists responsible for the development are still testing the software. 
Advantages of this solution are:

- preparing the content for one product and saving it in a file that will be usable again in another product;

- exchanging sources with colleagues and using the teaching content created by anyone else;

- taking own teaching materials in case the teacher moves to a school with another type of IWB;

- reading electronic materials provided by organizations, they can be provided in another format which saves time and money spent on the quality of these sources;

- schools will be more freehanded in IWB choice to choose the most suitable for their needs.

\section{Teachers' competences}

To use IWB in education process on a professional level, teachers have to acquire new didactictechnologic skills and competences. The usage of interactive whiteboard systems in each method of education supposes the existence of different integrated, resp. complex abilities of teachers (in the field of PC literacy, digital literacy, teacher's mastership, etc.). There remains the following question: the specification of these abilities or competences. In other words which competences are decisive, which significantly influence the professional usage of these systems in education process. Forming and developing of such competences is needed to be integrated in preparing teachers for pre-primary education. Among the most important competences can be found:

1. Usage of interactive whiteboard tools (service of the audiovisual didactic technique, the IWB itself and its supplementary equipment - data/video projector, PC, tablet, visualizer, multifunctional styluses, voting system, camcorder, etc.).

2. Choice of teaching materials (analysis of the educational programme and materials from the point of view of suitability for the curriculum aims and requested outputs from pupils considering their age specificities).

3. Preparation of teaching materials for interactive whiteboards and their pedagogic assessment - ability to use multimedia technologies in education (use of basic software support and further sources, e.g. interactive flash animations, templates, quizzes, videos and sounds).

4. Following the multimedia technology development with regard to interactive whiteboards (software and supplementary sources updating, mapping the use development, mapping application results, problems with the use of interactive whiteboards, information about the possibilities of content creation, exchange of experience, methods, tips, suggestions in teacher's community, e.g. portals such as: veskole.cz, activboard.cz, smarttech.com, etc.

\section{IWB in pre-school institutions in Slovakia and in the USA}

Numerous pre-school institutions have integrated various types of interactive whiteboards to their classes which has evoked discussions about the fact whether these interactive systems can speed up some progress in preparation for education at elementary schools. Some researchers proved that innovations that personalize learning and actively involve pupils into the teaching process and support teachers may be effectively implemented in pre-school institutions.

One of the first researches realized in the USA (McManic et al., 2011) has proved that the use of IWB in pre-school institutions positively influences basic language and mathematic predispositions, psychomotor and technical skills of children. The study also pointed out the fact that children made significant progress in the following fields: early literacy, knowledge of printed signs, understanding phonological connections, principles of writing and mathematic skills. At the very beginning of this study only $46 \%$ of children were prepared to study reading. Six months later the increase in readiness up to $82 \%$ was noticed. Only $72 \%$ of pupils achieved adequate score in mathematical tests concerning their readiness for learning mathematics. Till the end of the research this percentage increased to $92 \%$. It has been proved that children who are familiar with these technologies beat in readiness those who 


\section{Acta Technologica Dubnicae \\ volume 2, 2012, issue 1}

did not know anything about these systems. Children's progress noticed in testing (in pre- and posttesting) was statistically so significant that the percentage of children who were not ready to go to the kindergarten decreased in the next period by using IWB. This result has been noticed by a group of experts from the field of pedagogic and ontogenetic psychology and special pedagogy. They deal with children's readiness for elementary education in the USA. Some external evaluators who conducted testing took part in this research and the final data analysis was made by independent statisticians (McManis et al., 2011).

In 2011 - a creativity oriented research of pre-school aged children has been made in Slovakia. Its aim was to assess whether it is possible to develop creativity and increase the level of acquired knowledge of pre-school age children by solving interactive tasks on IWB in the field of technical education. It has been proved that a statistically significant difference was noticed between the input and output creativity measuring in the experimental group: the file of multimedia presenting exercise-books presented by interactive whiteboard containing tasks from the field of technical education applied in the education process at pre-primary level of education positively influenced the development of creative abilities of children. After the experimental verification of the assumption about increasing the level of acquired knowledge, the following fact was confirmed: children in the experimental group reached a significantly higher score in particular activities than those ones in the reference group.

On the basis of the above standpoints M. Červeňanská (2011, p. 123) states that: "the interactive whiteboard as a didactic technique sharing information by multimedia presenting exercise-books as teaching tools applied in the education process in pre-primary education increases the level of acquired knowledge of children at pre-primary age and the use of the interactive whiteboard as a didactic technique in the education process at the pre-primary level of education can be evaluated as a motivation source very positively."

With reference to the above mentioned research we would like to draw the reader's attention to the following skills and abilities of children at pre-primary education level which can be developed by using the interactive whiteboard systems and relevant teaching tools:

1. Psychomotor capacity, principles of critical and creative thinking.

2. Communication in mother tongue.

3. Mathematical skills and basic skills in the field of science and technology.

4. Digital skills.

5. Learning how to learn.

6. Interpersonal, intercultural, social and civil competences.

7. Business competences, competences of active approach.

8. Cultural reception.

\section{Conclusion}

Finally we would like to emphasize the importance of developing children's creative abilities in the field of technical education by the use of interactive whiteboards that is connected with the development of other competences. It is also important to be aware of the fact that if the use of this technology is not based on an effective teaching method or it is not connected with an interaction support, such an education will bring just a small or no result. It is the responsibility of the teacher, what kind of interactive teaching materials s/he will prepare to involve young learners into the education process, to motivate them and to let them have the feeling of an active participation in the running actions. This depends on factors like: teacher's preparation for work with relevant technologies, level of their competences, training and support (provided by the employer and government, too) that are necessary to maximalize efficiency of these means. 


\section{Acta Technologica Dubnicae \\ volume 2, 2012, issue 1}

\section{References}

BREČKA, P.: Spoločný štandard pre interaktívne tabule. In: Didaktika. Iura Edition, vol. 2, 2011, no. 1, p. 31-32.

ČERVENANSKÁ, M. - MELUŠOVÁ, J.: Využitie analýzy hlavných komponentov pri znázornení výsledkov pedagogického experimentu s interaktívnou tabul'ou. In: Forum Statisticum Slovacum. Bratislava: Slovenská štatistická a demografická spoločnost', 2011, p. 121-125.

ČERVEŇANSKÁ, M.: Interaktivna tabul'a ako didaktická pomôcka a zdroj motivácie vo výchovnovzdelávacom procese [Doctoral thesis]. Nitra: PF UKF v Nitre, Katedra techniky a informačných technológií, 2011.

DEVNEY, L: Survey reveals educators' most valued technologies. In: eSchool News, vol. 14, 2011, no 3.

MAROŠ, M.: Využívajú učitelia výučbový softvér? In: VII. vedecká konferencia doktorandov a mladých vedeckých pracovníkov: zborník z medzinárodnej konferencie. Nitra: FPV UKF, edícia Prírodovedec č. 206, 2006, p. 644-647.

McMANIS, L. D. - McMANIS, M. H. - GUNNEWIG, S. B.: Relationship of the TeachSmart $\mathbb{}$ Learning System with Literacy and Mathematics Outcomes for Preschoolers. [10.11. 2011]. http://www.earlychildhood.com/Resources/TeachSmart-EfficacyStudy-2011-Fire.pdf

STANSBURY, M.: New standard makes whiteboard content more accessible. In: eSchool News, vol. 13, 2010, no. 4, p.18.

QUASHIE, V.: How interactive is the interactive whiteboard? In: Mathematics Teaching, 2009, no. 214, p. 33-38.

ZÁRYBNICKÁ, R.: Př́padová studie využití interaktivní tabule ve výuce [Baklářská práce]. Praha: FEL ČVUT v Praze, 2007. 